\title{
POLA ASUH ORANG TUA DALAM PEMBELAJARAN DARING SELAMA COVID-19
}

\section{Rury Prissa Sonnie, Firman dan Rusdinal}

Universitas Negeri Padang Sumatera Barat, Indonesia

Email: ruryprissasonnie36@gmail.com, firman@konselor.org dan rusdinal@fip.unp.ac.id

\begin{abstract}
Covid-19 is an outbreak that is almost infecting the whole world including Indonesia. Until January 2021, almost 1 million people were declared positive for Covid-19. With the Covid-19 outbreak, there are many changes in almost all elements in the community. Not only in the field of health, economy, social but also in the field of education. With the issuance of the Regulation of the Ministry of Education so that online learning is enforced for school-age children. Therefore, it takes the role of parents in the education of the child by applying the right parenting patterns for the child during home study. This study uses qualitative research, sampling with purposive sampling that is parents who have school-age children. Data collection techniques with observations and interviews. In online learning parents apply a pattern of autocracy, democracy and permissive parenting. But by changing the way children learn from home school, of course, not all parents can apply a good parenting pattern for the child because of the demands of working parents. Therefore, to be able to provide motivation for children in learning parents need to provide a sense of security, comfortable in learning children, provide rewards and still communicate to children in between busy parents work.
\end{abstract}

Keywords: Covid-19; parenting patterns; online learning

\begin{abstract}
Abstrak
Tujuan dilakukan penelitian ini adalah untuk mengetahui pola asuh yang diterapkan orang tua dalam pembelajaran daring selama Covid-19. Penelitian ini menggunakan penelitian kualitatif, pengambilan sampel dengan purposive sampling yaitu orang tua yang memiliki anak usia sekolah. Teknik pengumpulan data dengan observasi dan wawancara. Hasil yang didapat bahwa dengan berubah cara belajar anak dari sekolah ke rumah tentu tidak semua orang tua bisa menerapkan pola asuh yang baik bagi anak karena tuntutan orang tua yang juga bekerja. Sehingga tidak semua orang tua menerapkan pola asuh demokrasi, tetapi juga pola asuh otokrasi dan permissive. Oleh karena itu, untuk dapat memberikan motivasi bagi anak dalam belajar orang tua perlu memberikan rasa aman, nyaman dalam belajar anak, memberikan reward serta masih melakukan komunikasi kepada anak di sela kesibukan orang tua bekerja.
\end{abstract}

Kata kunci: covid-19; pola asuh orang tua; pembelajaran daring 


\section{Coresponden Author}

Email: ruryprissasonnie36@gmail.com, Artikel dengan akses terbuka dibawah lisensi

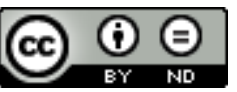

\section{Pendahuluan}

Akhir-akhir ini seluruh dunia dihebohkan dengan salah satu penyakit langka yang hampir menyerang dunia kesehatan yang dikenal dengan Coronavirus Diseases 2019 atau yang lebih kenal dengan Covid-19. Covid-19 merupakan suatu wabah yang hampir menjangkit diseluruh dunia termasuk Indonesia. Hingga Januari 2021 ini hampir 1 juta orang dinyatakan positif Covid-19. Dengan adanya wabah Covid-19 ini banyak terjadi perubahan dihampir semua elemen di masyarakat. Tidak hanya dibidang kesehatan, ekonomi, sosial namun juga terjadi pada bidang pendidikan. Perubahan pola pendidikan yang dulunya anak ke sekolah bertatap muka dengan guru, namun sekarang harus belajar di rumah secara daring. Pembelajaran daring ditujukan kepada seluruh jenjang pendidikan dasar sampai dengan perguruan tinggi (Dongoran, 2020).

Hal ini sesuai dengan peraturan yang dibuat oleh Kemendikbud No. 4 Tahun 2020 tentang Pelaksanaan Kebijakan Pendidikan Dalam Masa Darurat Penyebaran Corona Virus Disease 2019 (Covid-19) melalui Surat Edaran Seketaris Jenderal No. 15 Tahun 2020 tentang Pedoman Pelaksanaan Belajar dari Rumah selama Darurat Bencana. Tujuan diberlakukan belajar dari rumah yaitu (1) Memastikan pemenuhan anak untuk mendapatkan layanan pendidikan selama Covid-19, (2) Melindungi warga satuan pendidikan dari dampak buruk Covid-19, (3) Mencegah penyebaran dan penularan Covid-19 di satuan pendidikan serta (4) Memastikan pemenuhan dukungan psikososial bagi pendidik, peserta didik dan orang tua/wali. Untuk itu pembelajaran di rumah tidak hanya tugas guru dalam pemberian tugas, namun diperlukan kerjasama antara seluruh pihak termasuk orang tua (Pakpahan \& Fitriani, 2020).

Dengan kebijakan pemerintah tidak hanya menuntut inovasi guru tetapi dimaksimalkan kembali peran orang tua dalam mengasuh, mendampingi dan memfasilitasi anak dalam belajar (Iftitah \& Anawaty, 2020). Peran sentral orang tua dalam pendidikan anak di era pendemi memberikan keberhasilan pada anak karena pada umumnya orang tua merupakan pendidik utama bagi anak (Trisnawati \& Sugito, 2020). Kebijakan belajar dari rumah (Dewi \& Khotimah, 2020), secara positif memberikan banyak waktu antara anak dan orang tua untuk saling interaksi dan lebih mengenal anggota keluarga. Dimana secara tidak langsung, kebijakan belajar dan bekerja dari rumah telah mengembalikan fungsi keluarga sebagai pusat segala kegiatan dan tempat utama terjadinya pendidikan bagi anak. Untuk itu, dibutuhkan pola pengasuhan yang tepat dalam pendidikan anak di rumah.

Pola asuh orang tua menurut (Latifah, 2020) adalah cara orang tua mendidik anaknya sebagai perwujudan rasa tanggung jawab dan rasa sayang terhadap anak, agar 
anak memiliki perilaku atau tabiat yang baik ketika sudah dewasa Pola asuh setiap orang tua terhadap anak berbeda, hal tersebut dilandasi dari keadaan ekonomi, cara pandang dan pendidikan orang tua. Metode pola asuh yang digunakan orang tua pada anak sebagai faktor utama yang memilih potensi dan karakter seseorang anak. Ada banyak jenisjenis pola asuh yang sering sebagai panduan bagi siapa saja yang ingin mencetak generasi paripurna buat diandalkan bagi kemajuan bangsa ke depan. Jenis pola asuh ini memiliki karakter yang berbeda- beda (Putro, Amri, Wulandari, \& Kurniawan, 2020).

Menurut (Anggraeni, Hidayati, Khoirulliati, \& Farisia, 2020) bentuk pola asuh orang tua bervariasi, tergantung cara pola asuh keluarga dalam mendidik anak di rumah. Beberapa jenis pola asuh yang ada dalam keluarga antara lain (1) pola asuh otoriter, (2) pola asuh liberal, (3) pola asuh demokratis. Apalagi dalam keluarga yang terdiri dari orang tua tidak hanya memiliki fungsi dalam hal memberikan afeksi (kasih sayang), sosialisasi (penanaman nilai-nilai), namun juga fungsi ekonomi dalam pemenuhan kebutuhan anak. Dengan begitu, tidak jarang banyak orang tua yang sibuk dalam bekerja justru mengurangi intensitas mereka dalam membimbing anak. Hal tersebut menggambarkan hilangnya fungsi sosial keluarga salah satunya dimana tugas mendidik anak, sebagian diserahkan pada lembaga pendidikan yaitu sekolah (Khaeruddin, 2002).

Padahal pola asuh yang diterapkan orang tua selama belajar daring sangat dibutuhkan sehingga orang tua bisa memahami bahwa dukungan dan peran orang tua sangat diperlukan baik mendampingi, membimbing dan mengarahkan anak dalam proses belajar (Fatmawati, Ismaya, \& Setiawan, 2021). Hal ini tidak terlepas dari beberapa faktor menurut (Cahyati \& Kusumah, 2020) berupa karakteristik orang tua, kesabaran, intelegensi akan mempengaruhi kemampuan orang tua untuk memenuhi tuntutan peran sebagai orang tua dan tingkat sensitivisme terhadap kebutuhan anak.

Dalam pengasuhan ditemukan orang tua yang mengalami kesulitan dalam membimbing anak sehingga memberikan disiplin keras yang berakibat timbulnya kemerosotan dalam kualitas dalam pengasuhan (Dewi \& Khotimah, 2020). Tidak hanya itu ada yang memberikan kebebasan kepada anak dalam bertindak, ada orang tua yang selalu melindungi anak, ada yang mengawasi anak secara berlebihan, ada yang memberikan jarak kepada anak serta ada orang tua yang menganggap anak sebagai teman sehingga muncul keterbukaan diantara mereka. Tentu dengan cara pengasuhan orang tua ada yang berpengaruh positif dan negatif serta memiliki kelebihan dan kekurangan. Untuk itu pola asuh yang diterapkan orang tua harus disesuaikan dengan kebutuhan anak. Meskipun dengan cara yang berbeda, tetapi memiliki tujuan untuk menyelesaikan tugas sekolah yang diberikan guru kepada anak ( $\mathrm{Ng}$ et al., 2020).

Ketepatan orang tuadalam menerapkan pola asuh yang sesuai dengan konteks dan kebutuhan anak ternyata menumbuhkan motivasi dan kesiapan belajar anak (Anggraeni et al., 2020). Hal ini sesuai dengan pendapat (Sudjana, 1995) bahwa motivasi penting pada pembelajaran karena menjadi salah satu faktor penyebab siswa belajar. Motivasi dapat mempengaruhi sikap apa yang seharusnya anak ambil dalam usaha untuk belajar. Tentu motivasi setiap anak berbeda-beda, sehingga motivasi belajar perlu diperhatikan untuk mencapai tujuan dari belajar itu sendiri. Apalagi 
dengan Covid-19 yang mengharuskan anak untuk aktif dalam setiap pembelajaran agar tidak tertinggal. Tentu perlu adanya perhatian dari orang tua selama anak belajar di rumah untuk menggerakkan motivasi anak dalam belajar. Perhatian orang tua tidak cukup berupa finansial tetapi juga segi moral dengan memberikan lingkungan yang nyaman dan harmonis sehingga membentuk suasana belajar yang kondusif bagi siswa belajar di rumah selama Covid-19.

Berdasarkan observasi awal yang peneliti lakukan di masa Covid-19 ini masih ditemui anak- anak di jam belajar seperti di hari senin-sabtu masih berkeliaran diluar rumah untuk bermain. Padahal seharusnya anak masih diawasi orang tua untuk belajar online. Sehingga peneliti beranggapan bahwa orang tua belum berperan dalam pendidikan anak salah satunya menerapkan pola asuh yang baik bagi anak selama Covid-19. Berdasarkan wawancara awal yang peneliti lakukan kepada Sri budi orang tua dari RL yang merupakan siswa kelas 7 SMP dalam mengajarkan anaknya belajar online harus dikerasi, karena menurutnya jika anaknya tidak dikerasi dalam belajar anaknya cenderung acuh. Begitupun wawancara yang peneliti lakukan kepada Aprizen bahwa dalam belajar daring ini dia tidak punya waktu dalam memberikan asuhan kepada anaknya, apalagi dia dan suaminya juga bekerja sehingga ada waktu untuk anak ketika sore. Padahal tugas yang diberikan guru kepada anaknya itu dilakukan di pagi hari sehingga harus dikumpul hari itu juga.

Tidak hanya itu, dari hasil Penilaian Akhir Semester (PAS) yang telah diterima peserta didik masih banyak ditemui matapelajaran yang masih belum tuntas. Menurut salah seorang guru di salah satu SMP di Kec. Rambatan mengatakan bahwa sebenarnya di masa Covid ini lebih mudah peserta didik untuk mendapatkan nilai bagus apalagi dengan adanya berbagai sumber belajar seperti internet dan tidak hanya itu bahkan guru- gurupun memberikan modul untuk memudahkan para peserta didik namun hasil PAS mereka masih banyak yang belum tuntas dikarenakan kurangnya perhatian orang tua serta motivasi dari peserta didik itu sendiri.

Tentunya dengan pola asuh yang baik dari rumah akan meningkatkan motivasi belajar pada siswa yang akan mendorong semangat belajar dan meraih hasil belajar yang optimal. Siswa yang memiliki motivasi yang tinggi akan memiliki energi positif dan konsentrasi yang kuat saat proses pembelajaran berlangsung. Untuk itu peneliti tertarik mengkaji bagaimana pola asuh yang diterapkan orang tua yang berimplikasi kepada motivasi belajar anak selama Covid-19.

\section{Metode Penelitian}

Penelitian ini menggunakan pendekatan kualitatif deskriptif yang mencoba untuk mendeskripsikan dan menganalisis fenomena sosial yang terjadi secara apa adanya ( $\mathrm{J}$, 2004). Penelitian ini dilakukan di Jorong Pabalutan, Nagari Rambatan. Pengambilan informan dengan cara purposive sampling yaitu orang tua yang memiliki anak usia sekolah dengan kriteria orang tua yang memiliki anak sekolah dasar serta anak yang baru masuk sekolah menengah pertama serta orang tua itu sendiri. Teknik pengumpulan data dilakukan dengan observasi serta wawancara. Teknik Analisis data yang peneliti 
lakukan yaitu reduksi data, penyajian data dan kesimpulan atau verifikasi ( $\mathrm{Ng}$ et al., 2020).

\section{Hasil dan Pembahasan}

\section{Belajar Anak Selama Covid-19}

Sekolah merupakan tempat anak untuk mendapatkan ilmu pengetahuan dan dapat mengubah prilaku mereka menjadi lebih baik. Namun dengan adanya Covid-19 masuk ke Indonesia pada awal tahun 2019, dengan kebijakan pemerintah membuat pembelajaran di sekolah dirubah dengan belajar daring di rumah. Oleh karena itu, perlu peranan orang tua dalam membantu peserta didik dalam memudahkan mereka untuk belajar sehingga motivasi belajar mereka tidak menurun. Permasalahan sekarang tidak hanya itu saja, ternyata dengan perubahan cara belajar membuat kendala-kendala tidak hanya bagi siswa namun orang tua juga.

Belajar yang dulu tatap muka dengan guru, jika ada yang tidak paham langsung ditanyakan serta sebelum mengerjakan tugas siswa diberi arahan yang jelas dari guru mereka dan bisa bertanya saat itu juga jika mengalami kendala, sekarang mereka harus memahami sendiri pembelajaran dan tugas-tugas yang diberikan guru. Sekarang siswa harus belajar menggunakan gawai atau smartphone mereka untuk mengakses tugas yang diberikan guru, kebanyakan dari pembelajaran mereka tidak semua diberi arahan oleh guru malahan ada tugas yang langsung mereka memahami sendiri dengan mencari dengan gawai sehingga ini menyulitkan mereka. Adapun wawancara yang penulis lakukan, bahwa saat tatap muka saja mereka belum paham, apalagi dengan belajar online dengan diberikan tugas mereka disuruh memahami sendiri. Selain itu, orang tua mereka harus mengeluarkan biaya tambahan untuk kuota internet. Walaupun ada bantuan pemerintah dengan pemberian kuota internet dengan rincian kuota utama 5 GB yang bisa digunakan untuk mengakses internet dalam mencari materi dan juga ada kuota tambahan 45 GB yang bisa digunakan untuk akses Whatshapp, Zoom meeting, Google Classroom dan lain-lainnya. Namun disisi lain tentu dengan belajar dirumah orang tua lebih bisa memperhatikan anak mereka seperti kegiatan belajar. Untuk itu diperlukan pola asuh yang dapat membangkitkan semangat anak dalam belajar online. Namun tidak semua orang tua memiliki pemahaman yang sama, meskipun dengan tugas yang sama.

\section{Pola Asuh Orang tua}

Orang tua memiliki peranan penting dalam pendidikan anak karena orang tua merupakan tempat pertama dan utama dalam pengaushan anak. Pola asuh merupakan suatu cara yang dilakukan orang tua dalam memberikan pengasuhan, bimbingan atau arahan dan masukan kepada anak yang disesuaikan dengan kebutuhan anak. Namun, tidak semua orang tua bisa menerapkan pola asuh yang baik untuk pendidikan anak. Jorong Pabalutan merupakan salah satu bagian dari Nagari Rambatan, Kec. Rambatan, didaerah ini banyak ditemukan anak usia sekolah baik dari Sekolah Dasar maupun Sekolah menengah. Dengan adanya Covid tentu membawa dampak kepada orang tua dalam menjalankan pola pengasuhan apalagi anak harus belajar di rumah selama pendemi yang terjadi dari bulan maret 2019. Hal ini dikarenakan tidak semua 
orang tua yang memiliki anak usia sekolah bekerja sebagai Ibu Rumah Tangga ada dari mereka yang juga ikut bekerja. Berdasarkan wawancara yang peneliti lakukan kepada Ibuk AP dia mengatakan bahwa selama anak dia belajar dirumah dia tidak bisa memperhatikan kebutuhan belajar anak apakah dia kesulitan belajar karena kesibukannya dalam bekerja sehingga waktu untuk anak hanya ada pada malam hari dan itupun anaknya telah selesai mengerjakan tugas sekolah. Hal ini dikarenakan kebanyakan tugas sekolah anaknya dibuat hari ini dan dikumpulkan sesuai jam belajar.

Selain itu, ada beberapa orang tua yang menerapkan pola asuh otokrasi. Pola asuh otokraksi adalah pola asuh yang lebih menekankan kepada keinginan orang tua dan anak harus menuruti apa yang orang tua katakan sehingga banyak dari anakanak ketika orang tuanya tidak ada di rumah mereka malas untuk mengikuti aturanaturan yang ada di rumah. Berdasarkan wawancara yang peneliti lakukan kepada Ibu Diba yang mengatakan bahwa dia sering mengerasi anaknya dalam belajar, menurutnya ini yang akan membentuk anaknya karena kalau tidak anaknya terlalu santai belajar dan tidak tahu dengan aturan. Apalagi sejak pandemi dia yang harus bekerja bersama suami tentu agak susah untuk membimbing anaknya dalam belajar.

Selain itu, pola asuh demokrasi merupakan pola asuh yang diharapkan untuk dapat diterapkan untuk tumbuh kembang anak karena dapat menumbuhkan rasa percaya diri, semangat serta dapat mengendalikan diri dan mengurangi stress mereka dalam belajar. Apalagi dengan pandemi anak harus belajar dirumah tentu hal ini merupakan hal yang baru bagi mereka sehingga dibutuhkan kerjasama yang baik bagi orang tua yang memiliki anak usia sekolah. Berdasarkan wawancara yang peneliti lakukan kepad HB bahwa dia selalu membimbing anaknya dalam belajar, mencari tahu kesulitan anaknya. Hal ini dilakukannya dikarenakan dia memang sebagai Ibu Rumah Tangga sehingga dibalik kesibukannya masih bisa memperhatikan aktivitas anak selama di rumah.

Berdasarkan hasil penelitian orang tua dalam menerapkan pola asuh tidaklah sama satu sama lain. Hal ini sejalan dengan pendapat (Adawiah, 2017) bahwa pola asuh yang diterapkan orang tua mengarah pada pola asuh situasional dimana memungkinkan orang tua menerapkan pola asuh fleksibel, luwes yang disesuaikan dengan kondisi dan situasi saat itu.

Hal yang dapat dilakukan untuk pendidikan anak dengan memberikan pendampingan selama mereka belajar jika pun sibuk hendaknya orang tua masih bisa mehubungi anak- anak di sela bekerja untuk menanyakan bagaimana tugas sekolah mereka sehingga anak merasa orang tua juga ikut serta dalam pendidikannya. Selain itu dapat dilakukan dengan memberikan lingkungan belajar yang nyaman kepada anak. Kebanyakan orang tua selama anaknya belajar di rumah, anaknya diikut sertakan dalam pengerjakan tugas rumah lainnya seperti memasak, mengasuh adiknya bahkan ada beberapa yang menyuruh anaknya untuk bekerja di ladang. Oleh karena itu, hendaknya orang tua memberikan lingkungan belajar nyaman sehingga anak fokus dengan pekerjaan atau tugas sekolah mereka saja. Serta, perlu juga anak 
diberikan reward berupa pujian bahwa mereka telah menyelesaikan pekerjaan sekolah dengan baik.

Hal ini sejalan pendapat (Augustine et al., 2017) bahwa pola asuh orang tua yang dilakukan orang tua dengan memberlakukan aturan-aturan, hadiah maupun hukuman cara orang tua menunjukkan otoritas dan memberi perhatian serta tanggapan. Selain itu, menurut pendapat (Kurniati, Alfaeni, \& Andriani, 2020) menyatakan bahwa salah satu peran keluarga adalah menciptakan lingkungan yang menyenangkan untuk belajar di rumah, serta menjalin hubungan dan komunikasi hangat dan penuh kasih sayang bersama anak. Dengan begitu maka anak akan merasa nyaman, aman, dan menyenangkan berada di lingkungan keluarga.

\section{Kesimpulan}

Covid- 19 tidak hanya menjangkit Indonesia saja namun telah menjangkau seluruh Dunia. Untuk itu, dalam belajar anak dibutuhkan kerjasama tidak hanya bagi guru saja namun orang tua juga harus ikut andil bagi pendidikan anak. Tentu hal ini dapat dilakukan dengan memberikan rasa aman, kasih sayang, perhatian bagi anak selama belajar di rumah sehingga anak merasa nyaman, tidak mudah stress dan dapat meningkatkan motivasi mereka dalam belajar. Sehingga apa yang diharapkan orang tua agar anaknya berprestasi dapat terlaksana dengan baik. 


\section{BIBLIOGRAFI}

Adawiah, Rabiatul. (2017). Pola asuh orang tua dan implikasinya terhadap pendidikan anak: Studi pada Masyarakat Dayak di Kecamatan Halong Kabupaten Balangan. Jurnal Pendidikan Kewarganegaraan, 7(1), 33-48.

Anggraeni, Cindra Suryaputri, Hidayati, Nur, Khoirulliati, K., \& Farisia, Hernik. (2020). Trend Pola Asuh Orang Tua Dalam Model Pembelajaran Blended Learning Pada Masa Pandemi Covid-19. Al-Hikmah: Indonesian Journal of Early Childhood Islamic Education, 4(2), 109-119.

Augustine, Matthew R., Testerman, Traci L., Justo, Julie Ann, Bookstaver, P. Brandon, Kohn, Joseph, Albrecht, Helmut, \& Al-Hasan, Majdi N. (2017). Clinical risk score for prediction of extended-spectrum $\beta$-lactamase-producing Enterobacteriaceae in bloodstream isolates. Infection Control \& Hospital Epidemiology, 38(3), 266-272.

Cahyati, Nika, \& Kusumah, Rita. (2020). Peran Orang Tua Dalam Menerapkan Pembelajaran Di Rumah Saat Pandemi Covid 19. Jurnal Golden Age, 4(01), 152159.

Dewi, Putu Audina Suksma Cintya, \& Khotimah, Husnul. (2020). Pola Asuh Orang Tua Pada Anak Di Masa Pandemi Covid-19. Seminar Nasional Sistem Informasi (SENASIF), 4(1), 2433-2441.

Dongoran, M. Fadli. (2020). Covid-19: Berkah Atau Bencana? Dalam Preventif Pandemi, 131.

Fatmawati, Erna, Ismaya, Erik Aditia, \& Setiawan, Deka. (2021). Pola Asuh Orang Tua Dalam Memotivasi Belajar Anak Pada Pembelajaran Daring. Jurnal Educatio FKIP UNMA, 7(1), 104-110.

Iftitah, Selfi Lailiyatul, \& Anawaty, Mardiyana Faridhatul. (2020). Peran Orang Tua Dalam Mendampingi Anak Di Rumah Selama Pandemi Covid-19. JCE (Journal of Childhood Education), 4(2), 71-81.

J, Lexi. (2004). Metodologi Penelitian Kualitatif. Bandung: Remaja Rosdakarya.

Khaeruddin, H. (2002). Sosiologi Keluarga. Yogyakarta: Nurcahya.

Kurniati, Euis, Alfaeni, Dina Kusumanita Nur, \& Andriani, Fitri. (2020). Analisis Peran Orang Tua dalam Mendampingi Anak di Masa Pandemi Covid-19. Jurnal Obsesi: Jurnal Pendidikan Anak Usia Dini, 5(1), 241-256.

Latifah, Umi. (2020). Kebijakan Penyelenggaraan Pendidikan Di Masa Pandemi Covid 19 Dan Relevansinya Dengan Pola Asuh Orang Tua Menurut Zakiah Daradjat. Iain Ponorogo.

Ng, Dianna L., Goldgof, Gregory M., Shy, Brian R., Levine, Andrew G., Balcerek, Joanna, Bapat, Sagar P., Prostko, John, Rodgers, Mary, Coller, Kelly, \& Pearce, 
Sandra. (2020). SARS-CoV-2 seroprevalence and neutralizing activity in donor and patient blood. Nature Communications, 11(1), 1-7.

Pakpahan, Roida, \& Fitriani, Yuni. (2020). Analisa pemanfaatan teknologi informasi dalam pembelajaran jarak jauh di tengah pandemi virus corona covid-19. Journal of Information System, Applied, Management, Accounting and Research, 4(2), 3036.

Putro, Khamim Zarkasih, Amri, Muhammad Adly, Wulandari, Nuraisah, \& Kurniawan, Dedek. (2020). Pola interaksi anak dan orang tua selama kebijakan pembelajaran di rumah. Fitrah: Journal of Islamic Education, 1(1), 124-140.

Sudjana, Nana. (1995). Penilaian hasil proses belajar mengajar. PT Remaja Rosdakarya.

Trisnawati, Wahyu, \& Sugito, Sugito. (2020). Pendidikan Anak dalam Keluarga Era Covid-19. Jurnal Obsesi: Jurnal Pendidikan Anak Usia Dini, 5(1), 823-831. 